\title{
Population Fluctuation and Infestation Rates of Ceratitis capitata (Wiedemann) (Diptera: Tephritidae) on Different Pomegranate Varieties in Hatay (Turkey)
}

\author{
Nihat Demirel ${ }^{1, \mathrm{a}, *}$ \\ ${ }^{1}$ Department of Plant Protection, Faculty of Agriculture, Hatay Mustafa Kemal University, 31034 Hatay, Turkey
} *Corresponding author

A R T I C L E I N F O A S T R A C T

Research Article

The Mediterranean fruit fly (Medfly), Ceratitis capitata (Wiedemann) (Diptera: Tephritidae), is a serious pest on pomegranate in Turkey. The purpose of this study was to determine population fluctuation and infestation rates of medfly on various pomegranate varieties in Hatay province of

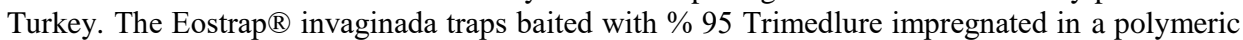
plug-type dispenser were used. The fruit infestation assessment was measured by a hundred fruits chosen randomly from ten trees in each of sampled orchard and checked for medfly punctures and infested fruits were counted. As a result of two-year investigations, this pest was found in six sites, which are located in Kırıkhan (Delibekirli, Kurtlu soğuksu) and Serinyol districts of Hatay province. In 2010, the highest mean of the catches per traps were recorded on 13 October (236.5), followed by 6 October (166.5), 29 September (145.5), 20 October (145.0) and 22 September (110.0) on 'Karamehmet+katırbaşı' varieties in Delibekirli village. Moreover, the highest mean of the catches per traps were recorded on 6 October (38.0), followed by 13 October (33.5), 20 October (17.0), 29 September (16) and 22 September (9) on 'Katırbaşı' varieties in Kurtlu soğuksu. In 2011, the highest mean of the catches per traps were recorded on 7 November (240.0), followed by 14 November (162.5), 31 October (100.5), 24 October (58) and 21 November (32) on Katırbaş1 and Hicaz varieties of Serinyol district. The highest percentages of infestation rates were observed at orchard II (42) on 'Karamehmet+katırbaşı', followed orchard I (37) on 'Karamehmet+katırbaşı', orchard III (7) on 'Katırbaşı' and orchard IV (3) on 'Katırbaşı' varieties 2010. In addition, the highest percentages of infestation rates were observed at orchard I (44) on 'Katırbaş1', followed at orchard II (8) on 'Hicaz' varieties 2011. The highest mean of medfly was observed in October and September in 2010, and in November and October in 2011 due to ripening and harvesting time of fruits. The medfly caused significantly more infestation rates on 'Karamehmet+katırbaşı' and 'Katırbaşı' pomegranate than 'Hicaz' pomegranate.

\section{Introduction}

The Mediterranean fruit fly (Medfly), Ceratitis capitata (Wiedemann) (Diptera: Tephritidae), is one of the most important fruit pests throughout the world (White and ElsonHaris, 1994). The Medfly is a polyphagous species attacking over 350 different hosts (Weems, 1981; Liquido et al., 1991). This pest overwinters as pupae in the soil under the host plant and they appear on apricot and peach from June to July (White and Elson-Haris, 1994), on pomegranate from late July to August (Çardak, 2015; Çalıklı, 2015; Demirel, 2016; Demirel et al., 2018). The females lay eggs below the skin of the host fruits, which are destroyed by larval feeding (White and Elson-Haris, 1994).

Trimedlure is the most effective available attractant for medfly male (Beroza et al., 1961). Trimedlure containing Jackson and McPhail traps were important detection and monitoring (Leonhardt et al., 1989; Warthen et al., 1997; Gilbert and Bingham, 1999; Demirel and Akyol, 2017; Kılıç and Demirel, 2018) and control for medfly (Niccoli et al., 1991; Demirel et al., 2018; Demirel, 2019a,b). A purpose of the current study was to determine population fluctuation and infestation rates of $C$. capitata (Wiedemann) (Diptera: Tephritidae) on various pomegranate varieties in Hatay province of Turkey.

\section{Materials and Methods}

The current study was conducted in 2010-2011 in six pomegranate orchards in Kirıkhan and Serinyol districts of Hatay province. The studies were conducted by using the Eostrap ${ }^{\circledR}$ invaginada traps (Sanidad Agricola Econex, 
Santomera, Murcia, Spain) baited with \% 95 Trimedlure, (formulated in a polymeric plug-type dispenser, duration 90 days) (Sanidad Agricola Econex, Santomera, Murcia, Spain) and dichlorvos or 2.2- dichlorovinyl dimethyl phosphate (DDVP) tablet (Sanidad Agricola Econex, Santomera, Murcia, Spain). In 2010, the study was conducted at four pomegranate orchards located in villages Delibekirli (orchard I), Delibekirli (orchard II), Kurtlu soğuksu (orchard III), Kurtlu soğuksu (orchard IV) in Kirıkhan district. A two pomegranate orchards located in Delibekirli have 'Karamehmet + Katırbaşı' varieties and other orchards located in Kurtlu soğuksu contain 'Katırbaşı' variety. A four studies were conducted from 21 July to 10 November 2010.

In 2011, the study was conducted at two pomegranate orchards located in Serinyol district of Hatay province. One of them contains 'Katırbaşı' and other contains 'Hicaz'variety. Both studies were conducted from 8 August to 5 December 2011. One trap for each orchard was used in both year. Each of the trap baited with trimedlure was placed $1.5 \mathrm{~m}$ above ground and checked weekly, caught medfly were counted and removed from the traps. All data were analyzed by analysis of variance (ANOVA) with using the SAS software (SAS Institute Inc., 1998). The fruit damage assessment was measured by the percentage of medfly punctures during the harvest time. For this purpose, except from the trees with traps, a hundred fruits were chosen randomly from ten trees in each of sampled orchard and checked for medfly punctures and infested fruits were counted.

\section{Results and Discussion}

A population fluctuation of Medfly were significantly different in each of the pomegranate variety. The pests were found in all sampled pomegranate orchards in 2010-

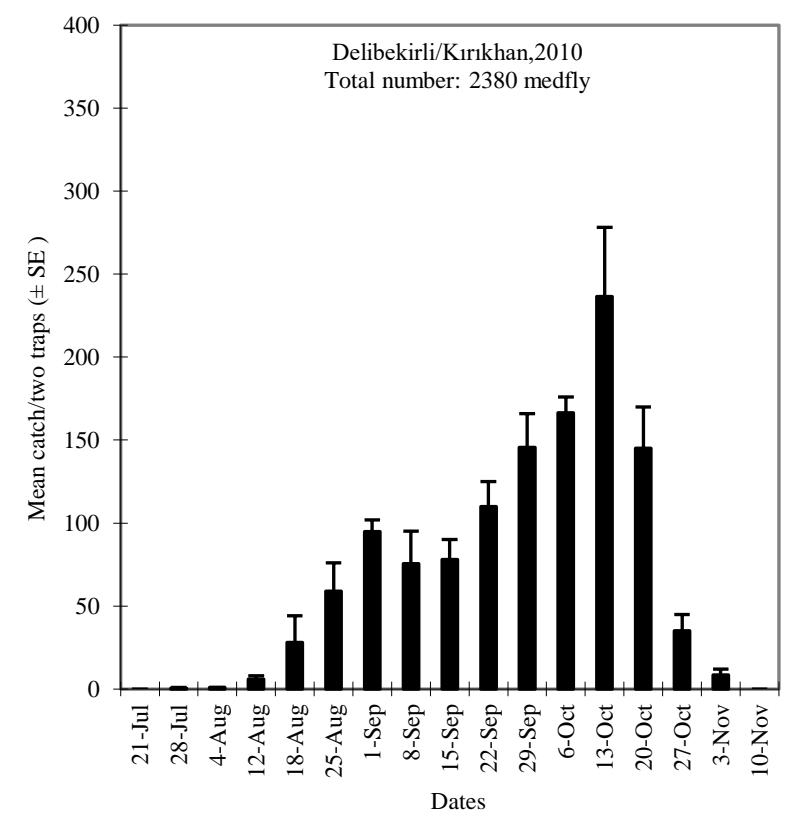

Figure 1. Mean $( \pm \mathrm{SE})$ of caught medfly adults in traps at Karamehmet + Katırbaşı pomegranate orchards in Delibekirli village of Kırıkhan district
2011. In 2010, two 'Karamehmet+Katırbaşı' pomegranate orchards were sampled in village of Delibekirli of Kirıkan district. A total of 2380 medfly adults were caught by two traps baited with trimedlure (Figure 1). The population fluctuation of medfly varied during the sampling period. The first adults were caught by traps on 28 July. The highest mean of the catches per traps were recorded on 13 October, followed by 6 October, 29 September, 20 October and 22 September. The largest percentages of medfly adults per traps was in October, followed by September.

A two 'Katırbaşı' pomegranate orchards were sampled in Kurtlu soğuksu of Kirıkhan district. A total of 257 medfly adults were caught by two traps (Figure 2). The first adults were caught by traps on 25 August. The highest mean of catches per traps were recorded on 6 October, followed by 13 October, 20 October, 29 September and 22 September. The largest percentages of medfly adults per traps was in October, followed by September.

In 2011, two pomegranate orchards containing 'Katırbaşı' and 'Hicaz' varieties were sampled in Serinyol district. A total of 1228 medfly adults were caught by two traps (Figure 3). The first adults were caught by traps on 19 September. The highest mean of catches per traps were recorded on 7 November, followed by 14 November, 31 October, 24 October and 21 November. The largest percentages of medfly adults per traps was in November, followed by October.

The current study indicated that the infestation rates of medfly were significantly different in each of the sampled variety. In 2010, the highest percentages of infestation rates were observed at orchard II (karamehmet+katırbaşı), followed orchard I (karamehmet + katırbaş1), orchard III (katırbaş1) and orchard IV (katırbaşı) (Figure 4). In 2011, the largest percentages of infestation rates were observed at orchard I (katırbaşı), followed at orchard II (Hicaz) (Figure 5).

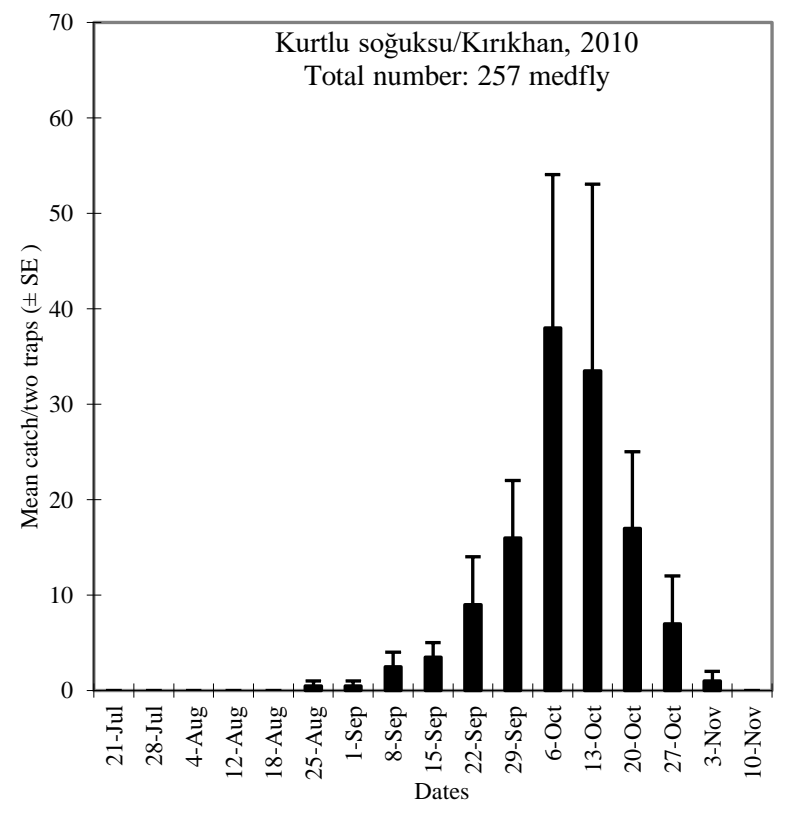

Figure 2. Mean $( \pm \mathrm{SE})$ of caught medfly adults in traps at Katırbaşı pomegranate orchards in Kurtlu soğuksu village of Kirıkhan district 


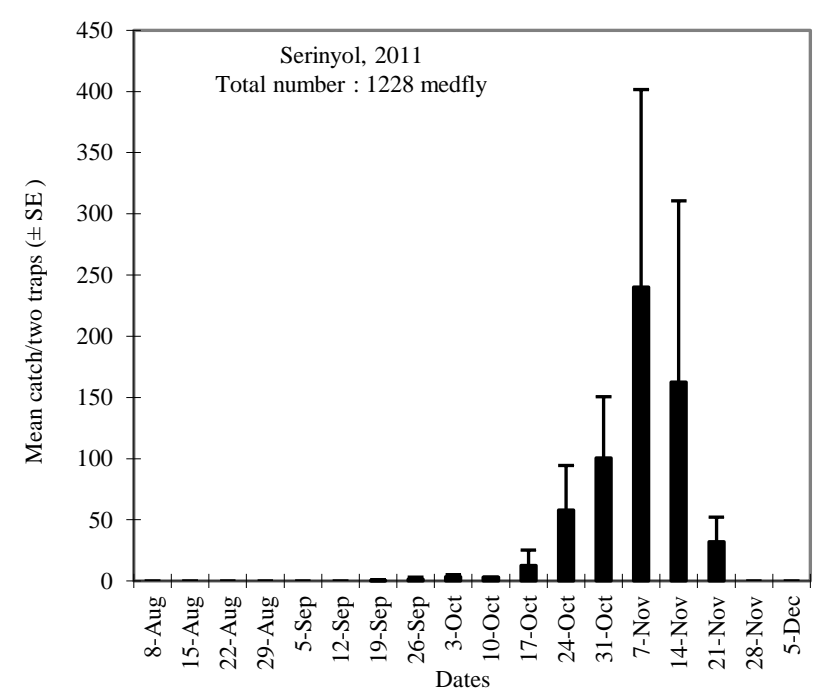

Figure 3. Mean $( \pm \mathrm{SE})$ of caught medfly adults in traps at Katırbaşı and Hicaz pomegranate orchards in Serinyol district

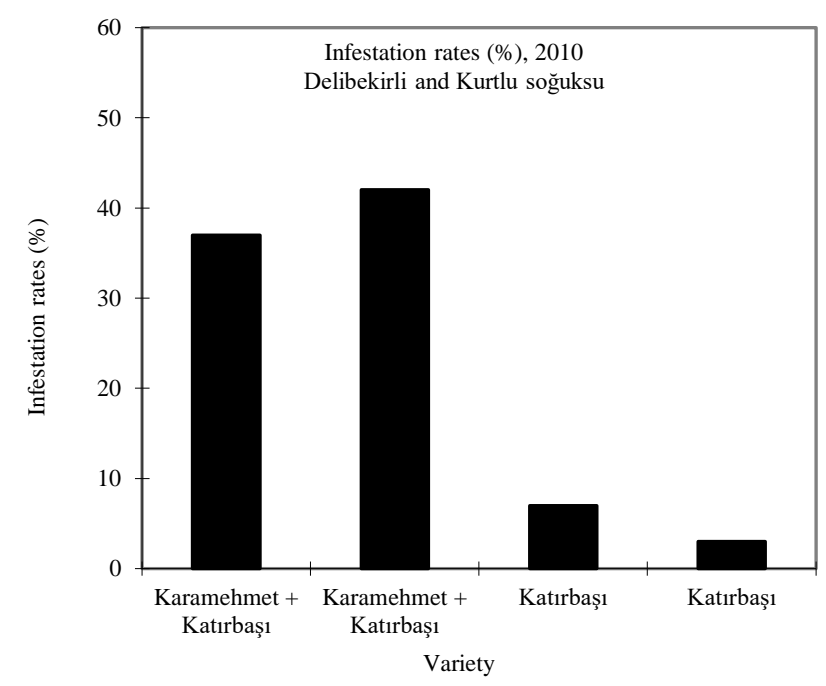

Figure 4. Infestation rates of medfly on different variety of pomegranate orchards in Delibekirli and Kurtlu soğuksu in 2010.

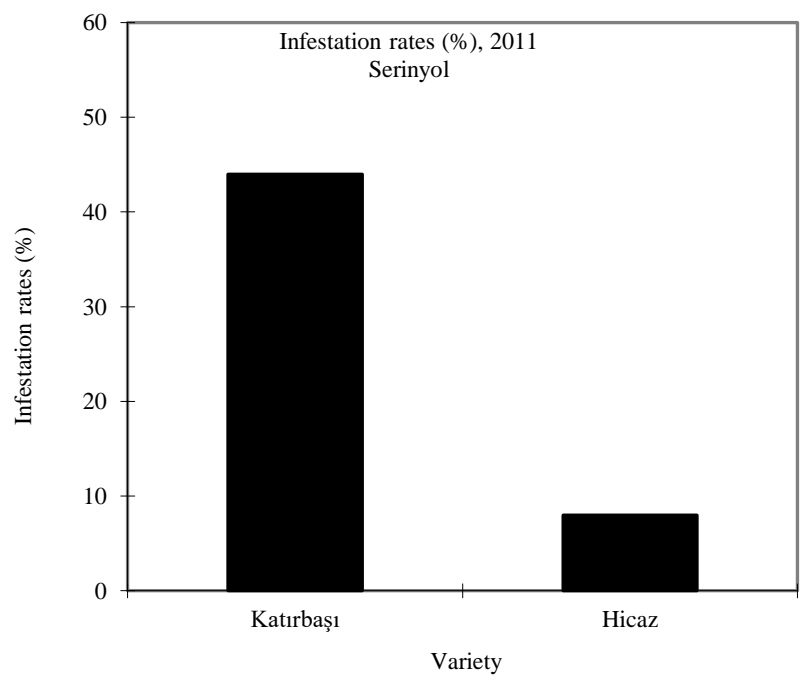

Figure 5. Infestation rates of medfly on different variery of pomegranate orchards in Serinyol district in 2011
The trimedlure was important detection and monitoring tools used for medfly male attractant (Leonhardt et al., 1989; White and Elson-Haris, 1994; Warthen et al., 1997; Gilbert and Bingham,1999; Jang et al., 2003; IAEA, 2003). According to previous studies, the population fluctuation of medfly varied for sampling periods and host plants. Hashem et al. (1987) reported that the population fluctuations of $C$. capitata in the north of Egypt occurred in October-November on Citrus, and in May-June on apricot and some early varieties of peaches. In addition, Demirel (2016) studied the population density of medfly on pomegranate orchards in Hatay province in 2012 and 2014. In 2012, a total of 2634 medfly adults were caught by six traps at six pomegranate orchards of Antakya district. According to study, the largest mean of catches per traps were recorded on 4 November (127.50), followed by 28 October (122.33), 18 November (59.67), 11 November (45.0), 14 October (39.67) and 21 October (29.83). In 2014, a total of 1325 medfly adults were caught by four traps at four pomegranate orchards of Antakya district. According to study, the largest mean of catches per traps were recorded on 8 November (69.5), followed by 15 November (67.25), 1 November (53.0), 22 November (33.75), 26 October (32.25), 29 November (20.25) and 19 October (19.0).

Several studies were also conducted to evaluate the percentages infestation rates of medfly on various host plants. Fimiani (1989) reported that infestation rates to fruit crops is frequently high and may reach 100 percent. Hashem et al. (1987) reported that infestation levels of medfly were different in on apricots (74), grapefruits (49.5), sour oranges (42.5), guavas (36.5), peaches (24), mandarins (16), baladi oranges (13.3), navel oranges (8.5), mangoes (8.6) and valencia oranges (7.5). In addition, Demirel and Akyol (2017) reported that percentages of infestation rates with medfly on satsuma mandarin were 10.91 in 2011 and 8.56 in 2012. In addition, Üçpınar and Ünlü (2019) reported that percentages of infestation rates of medfly on peach orchards were 5 and 2 in Ekmekkoçu, 3 and 2 in Hasanköy, 96 and 96 in Hatıp, 94 and 100 in Karahüyük, 0 and 2 in Yenibahçe location in 2017-2018. Yıldırım and Başpınar (2011) found that infestation rate of pomegranate orchards during harvest time was 2.20 percent. Kasap and Aslan (2016) reported that the infestation rates of medfly on Acco pomegranate was 5.2\% in Adana province. Demirel (2016) reported that the percentages of infestation rates of medfly were observed in each of the sampled orchard on different pomegranate varieties. According to study, in 2012, the highest damage ratios of medfly were observed at orchard II, followed by orchard VI, orchard I, orchard IV, orchard III and orchard $\mathrm{V}$ on 'Hicaz' pomegranate. In 2014, the highest damage ratios of medfly were observed at orchard IV (Katırbaş1), followed by orchard III (Katırbaşı), orchard II (Hicaz) and orchard I (Hicaz).

\section{Conclusion}

The current study was conducted by traps baited with trimedlure to determine the population fluctuation and infestation rates of medfly on different pomegranate variety in Hatay province of Turkey. As a result of twoyear investigations, this pest was found in six sites, which 
are located in Kirikhan and Serinyol districts of Hatay province. A population fluctuation of this pest was significantly higher in October and September than was in August and November in 2010. In addition, it was significantly higher in November and October than was in September in 2011. The current study resulted that the percentage infestation rates of medfly was different in each of the sampled variety. In 2010, the largest percentages of infestation rates of medfly were observed at orchard II (karamehmet + katırbaşı), followed orchard I (karamehmet + katırbaşı), orchard III (katırbaşı) and orchard IV (katırbaş1). In 2011, the largest percentages of infestation rates of medfly were observed at orchard I (katırbaşı), followed at orchard II (Hicaz).

\section{References}

Beroza M, Green N, Gertler SI. 1961. New attractants for the Mediterranean fruit fly. J Agric Food Chem 9: 361-365.

Çalıklı Ş. 2015. Akdeniz Meyve Sineği, Ceratitis capitata (Wiedemann) (Diptera: Tephritidae'nin mücadelesinde farklı cezbedicilerin kullanılması. Mustafa Kemal Üniversitesi. Fen Bilimleri Enstitüsü. Yüksek Lisans Tezi. Hatay, 65 pp.

Çardak M. 2015. Osmaniye İli Nar Bahçelerinde Akdeniz Meyve Sineği, Ceratitis capitata (Wiedemann) (Diptera: Tephritidae)'nin Yayıllışı, Populasyon Yoğunluğu ve Zarar Oranının Belirlenmesi. Mustafa Kemal Üniversitesi. Fen Bilimleri Enstitüsü. Yüksek Lisans Tezi. Hatay, 58 pp.

Demirel N. 2016. Population density and damage ratios of Mediterranean fruit fly Ceratitis capitata Wiedemann Diptera Tephritidae on pomegranate orchards in Turkey. Entomology and Applied ScienceLetters. 3(5): 1-7.

Demirel N. 2019a. Efficacy of various attractants to Mediterranean fruit fly, Ceratitis capitata (Wiedemann) (Diptera: Tephritidae) on persimmon fruits in Turkey. Fresenius Environmental Bulletin. 28(7): 5390-5397.

Demirel N. 2019b. Trapping genders of Ceratitis capitata (Diptera: Tephritidae) and other Dipteran with various attractants on pomegranate fruits in Turkey. Fresenius Environmental Bulletin. 28(4): 2937-2941.

Demirel N, Akyol E. 2017. Evaluation of mass trapping for control of Mediterranean fruit fly, Ceratitis capitata (Wiedemann) (Diptera: Tephritidae) in Satsuma mandarin in Hatay province of Turkey. International Journal of Environmental Agriculture Research. 3(12): 32-37.

Demirel N, Yıldırım AE, Kılıç G. 2018. Effectiveness of various attractants for Mediterranean fruit fly, Ceratitis capitata (Wiedemann) (Diptera: Tephritidae) on pomegranate fruits in Turkey. Fresenius Environmental Bulletin. 27(5): 3191-3198.

Fimiani P. 1989. Pest status; Mediterranean region. In: Robinson AS, Hooper G, eds. Fruit Flies; Their Biology, Natural Enemies and Control. World Crop Pests, 3(A):37-50. Amsterdam, Netherlands: Elsevier.
Gilbert J, Bingham RR. 1999. Insect Trapping Guide. California Department of Food and Agriculture. MF. 1-9.

Hashem AG, Saafan MH, Haris EJ. 1987. Population ecology of the Mediterranean fruit fly in the reclaimed area in the western desert of Egypt (South Tahrir sector). Annals of Agricultural Science, Ain Shams University (Cairo) 32(3): $1803-1811$.

IAEA. 2003. Trapping guidelines for area-wide fruit fly programmes. Insect Pest Control Section, International Atomic Energy Agency, Vienna, Austria.

Jang EB, Holler T, Cristofaro M, Lux S, Raw, AS, Moses AL, Carvalho LA. 2003. Improved Attractants for Mediterranean Fruit Fly, Ceratitis capitata (Wiedemann): Responses of Sterile and Wild Flies to (-) Enantiomer of Ceralure B1. J. Econ. Entomol. 96: 1719-1723.

Kasap A, Aslan, MM. 2016. The Monitoring the Population and Detection of the Loss Ratio of the Mediterranean Fruit fly (Ceratitis capitata Wied.) (Diptera: Tephritidae) By Pheromone Traps in Pomegranate and Persimmon Varieties. KSU J. Nat. Sci., 19(1):43-50.

Kılıç G, Demirel N. 2018. A population fluctuation and damage rates of Ceratitis capitata Wied.) (Diptera: Tephritidae) on persimmon fruits in Turkey. Fresenius Environmental Bulletin. 27(7): 5072-5077.

Leonhardt BA, Cunningham RT, Rice RE, Harte EM, Hendrichs J.1989. Design, effectiveness, and performance criteria of dispenser formulations of trimedlure, an attractant of the Mediterranean fruit fly (Diptera: Tephritidae). J.Econ. Entomol. 82 (3): 860-867.

Liquido NJ, Shinoda LA, Cunningham RT.1991. Host Plants of the Mediterranean Fruit Fly (Diptera Tephritidae): An annotated world review. Misc. Publ. Entomol. Soc. Am. $77: 1-52$.

Niccoli A, Sacchetti P, Lupi E.1991. Observations on the capture of Ceratitis capitata in peach orchards in Tuscany . Redia. 74: 641-658.

Üçpınar ŞN, Ünlü L. 2019. The Determination of Population Development and Infestation Rate of Mediterranean Fruit Fly (Ceratitis capitata (Wied)) in Peach Orchards in Meram (Konya) Province. Selçuk Journal of Agriculture and Food Sciences. 33(2): 67-73.

SAS Institute (1998). User's guide, version 6. SAS Institute, Cary, NC, USA.

Warthen JD, Cunningham RT, Leonhardt BA, Cook JM, Avery JW, Harte EM. 1997. Improved controlled-release formulations for a new trap design for male Mediterranean fruit flies the C\&C trap. J. Chem. Ecol. 23:1471-1486.

Weems HVJr, 1981. Mediterranean fruit fly, Ceratitis capitata (Wiedemann) (Diptera: Tephritidae). Entomology Circular, Division of Plant Industry, Florida Department of Agriculture and Consumer Services, 12 pp.

White IM, Elson-Harris MM. 1994. Fruit Flies of Economic Significance. Their Identification and Bionomics. Wallingford, UK, CAB International, $601 \mathrm{pp}$

Yıldırım EM, Başpınar H. 2011. Aydın ili nar bahçe-lerinde saptanan zararlı ve predatör türler, yayılışı, zararlı türlerden önemlilerinin popülasyon değişimi ve zararı. Türk. entomol. bült. 1 (3): 169-179. 